\title{
PENGARUH KEADILAN DISTRIBUTIF TERHADAP NIAT PINDAH KERJA: PENGUJIAN EFEK MEDIASI INSTRUMEN PROMOSI DAN PRESTASI KERJA
}

\author{
Mentari Maghfirani Riyadi \\ Fakultas Ekonomi Universitas Islam Indonesia \\ e-mail: mentari.maghfirani8@gmail.com \\ Mahmudi \\ Fakultas Ekonomi Universitas Islam Indonesia \\ e-mail: mah_mudi2001@yahoo.com
}

\begin{abstract}
This paper examines the effect of distributive justice on turnover intention by introducing promotion instrumentality as mediating variable and job performance as moderating and mediating variable. This study is motivated by the increasing number of employees turnover, particularly in banking industries. We conducted on-line survey toward 139 employees in banking industries in Indonesia. Based on the result of regression analysis, this research found that (1) distributive justice has a positive association with promotion instumentality, which, in turn promotion instrumentality has a negative influence on turnover intention, (2) The effect of promotion instrumentality on turnover intention is moderated by job performance, (3) distributive justice has a positive effect on job performance, and (4) job performance has a negative effect on turnover intention. However, based on path analysis the association of distributive justice on turnover intention tend to have direct effect which is not mediated by promotion instrumentality and job performance.
\end{abstract}

Keywords: Distributive Justice, Promotion Instrumentality, Job Performance, Turnover Intention. http://dx.doi.org/10.20885/jaai.vol19.iss1.art2

\begin{abstract}
Abstrak
Paper ini menguji pengaruh keadilan distributif terhadap niat pindah kerja dengan memasukkan instrumen promosi sebagai variabel mediasi dan prestasi kerja sebagai variabel moderasi dan mediasi. Penelitian ini dimotivasi oleh adanya tingkat perpindahan kerja karyawan yang semakin tinggi, khususnya di industri perbankan. Kami melakukan survey secara on-line terhadap 139 karyawan perusahaan perbankan di Indonesia. Berdasarkan hasil analisis regresi, penelitian ini menemukan bukti bahwa (1) keadilan distributi berpengaruh positif signifikan terhadap instrumen promosi, selanjutnya instrumen promosi berpengaruh negatif signifikan terhadap niat pindah kerja, (2) prestasi kerja memoderasi pengaruh instrumen promosi terhadap niat pindah kerja, (3) keadilan distributif berpengaruh positif signifikan terhadap prestasi kerja, dan (4) prestasi kerja berpengaruh negatif signifikan terhadap niat pindah kerja. Namun, berdasarkan analisis jalur, pengaruh keadilan distributif terhadap niat pindah kerja cenderung berpengaruh langsung yang tidak dimediasi oleh instrumen promosi maupun prestasi kerja.
\end{abstract}

Kata Kunci: Keadilan Distributif, Instrumen Promosi, Prestasi Kerja, Niat Pindah Kerja.

\section{PENDAHULUAN}

Penelitian ini bertujuan untuk menginvestigasi pengaruh keadilan distributif terhadap niat pindah kerja karyawan. Dalam penelitian ini juga diinvestigasi apakah instrumen promosi memediasi hubungan keadilan distributif terhadap niat pindah kerja. Selain itu, penelitian ini juga ingin menguji peran mediasi dan moderasi variabel kinerja dalam mekanisme perpindahan kerja. Penelitian ini didasari oleh penelitian terdahulu yang dilakukan Parker, 
Nouri, dan Hayes (2011) yang menemukan bahwa keadilan distributif memiliki pengaruh positif terhadap instrumen promosi, dan instrumen promosi berpengaruh negatif terhadap niat pindah kerja. Dalam penelitian tersebut ditemukan bahwa kinerja (job performance) memoderasi hubungan antara instrumen promosi dan niat pindah kerja. Parker, Nouri, dan Hayes (2011) tidak menguji pengaruh keadilan distributif terhadap prestasi kerja dan pengaruh prestasi kerja terhadap niat pindah kerja. Padahal berdasarkan penelitian yang dilakukan Nasurdin dan Khuan (2007) yang meneliti karyawan industri komunikasi di Malaysia membuktikan bahwa keadilan distributif dan keadilan prosedural berpengaruh positif terhadap kinerja karyawan. Selanjutnya berdasarkan penelitian Zimmerman dan Darnold (2007) ditemukan bahwa kinerja karyawan berpengaruh terhadap niat pindah kerja. Dalam penelitian ini diuji apakah variabel prestasi kinerja memediasi antara keadilan distributif terhadap niat pindah kerja. Penelitian ini juga ingin menguji peran prestasi kerja sebagai variabel moderasi antara instrumen promosi dan niat pindah kerja sebagaimana dilakukan Parker, Nouri, dan Hayes (2011).

Perpindahan kerja adalah salah satu perilaku karyawan yang seringkali menimbulkan dampak negatif bagi perusahaan. Dengan tingginya tingkat perpindahan kerja pada perusahaan maka akan menimbulkan berbagai potensi biaya, antara lain biaya pelatihan yang sudah diinvestasikan pada karyawan, tingkat kinerja yang dikorbankan, maupun biaya rekrutmen dan pelatihan kembali (Toly 2001). Adakalanya perpindahan kerja memiliki dampak positif bagi perusahaan. Dampak positifnya perusahaan tidak berkewajiban memberikan biaya tambahan baik berupa pesangon, tunjangan hari tua, dan kenaikan gaji. Selain itu perusahaan merasa diuntungkan jika perpindahan kerja digunakan sebagai kesempatan promosi bagi karyawan yang lain dalam organisasi yang sama (Sidartha dan Margaretha 2011). Hasil survey yang dilakukan sejak pertengahan tahun 2006-2007 oleh Managing Consultant PT. Watson Wyatt Indonesia menunjukkan tingkat perpindahan kerja untuk posisi-posisi penting (level manajerial atas) di industri perbankan adalah sebesar 6,3\% $7,5 \%$. Sedangkan tingkat perpindahan karyawan industri pada umumnya hanya berkisar 0,1\% - 0,74\% (Ridlo 2012).

Melihat bahwa tingkat perpindahan kerja yang tinggi lebih berpotensi menimbulkan dampak negatif, maka penting untuk dikethui faktor apa yang memengaruhi niat perpindahan kerja karyawan. Beberapa penelitian terdahulu telah menguji beberapa faktor yang yang memengaruhi perpindahan kerja, antara lain mentoring (Scandura dan Viator 1994), tatanan kerja fleksibel (Almer dan Kaplan 2002), gender (Dalton, Hill, Ramsay 1997), konflik kerja-keluarga (Pasewark dan Viator 2006), karakteristik personalitas (Harrel dan Eickhoff 1988) tekanan dan kelelahan kerja (Fogarty, Singh, Rhoads, dan Moore 2000), keadilan organisasi dan instrumen promosi (Parker et al. 2011; Parker dan Kohlmeyer 2005).

Penelitian yang menguji pengaruh keadilan organisasi terhadap perpindahan kerja belum banyak dilakukan. Penelitian empiris yang menguji pengaruh keadilan organisasi terhadap perpindahan kerja pernah dilakukan antara lain oleh Alexander dan Ruderman (1987), Parker dan Kohlmeyer (2005) serta Parker et al. (2011). Penelitian survei yang dilakukan Alexander dan Ruderman (1987) terhadap 2.800 pegawai pemerintah federal di Amerika Serikat menunjukkan bahwa keadilan distributif berpengaruh terhadap kepercayaan pada manajemen, niat pindah kerja, penilaian terhadap supervisor, konflik/harmoni, dan kepuasan kerja. Penelitian Parker dan Kohlmeyer (2005) menguji pengaruh keadilan organisasi terhadap perpindahan kerja di perusahaan Kantor Akuntan Publik di Amerika Serikat. Sementara itu, penelitian Parker et al. (2011) menambahkan variabel instrumen promosi yang memediasi hubungan antara keadilan organisasi terhadap perpindahan kerja. Penelitian Parker et al. (2011) juga menguji peran variabel kinerja sebagai variabel yang memoderasi hubungan antara instumen promosi terhadap perpindahan kerja. Penelitian mereka 
dilakukan di perusahaan Kantor Akuntan Publik di Amerika Serikat. Penelitian ini memperluas penelitian yang dilakukan Parker et al. (2011) dengan menguji peran variabel kinerja sebagai variabel mediasi-moderasi dalam model penelitian Parker et al. (2011) yang belum diuji. Responden penelitian diambil dari karyawan yang bekerja di perusahaan perbankan di Indonesia.

Peneliti ini menggunakan keadilan distributif untuk memprediksi niat pindah kerja karyawan. Keadilan distributif adalah presepsi karyawan atas keadilan dalam perusahaan atas dasar hasil (misal: gaji, bonus, promosi, dan jabatan) yang mereka terima (Greenberg 1990; Holtz dan Harold 2009). Dalam penelitian ini diuji apakah keadilan distribusi memengaruhi instrumen promosi, selanjutnya apakah instrumen promosi memengaruhi niat pindah kerja. Selain itu juga diuji apakah keadilan distributif memengaruhi kinerja karyawan, selanjutnya apakah kinerja karyawan memengaruhi niat pindah kerja. Apakah kinerja karyawan memoderasi hubungan instrumen promosi terhadap niat pindah kerja. Berdasarkan hasil survei terhadap 139 karyawan bank di Indonesia, penelitian ini menunjukkan bahwa keadilan distributif berpengaruh positif signifikan terhadap instrumen promosi. Instrumen promosi berpengaruh negatif signifikan terhadap niat pindah kerja. Penelitian ini juga menemukan bahwa keadilan distributif berpengaruh signifikan terhadap kinerja karyawan, dan selanjutnya kinerja karyawan berpengaruh negatif terhadap niat pindah kerja. Ditemukan bukti empiris bahwa kinerja karyawan memoderasi hubungan antara instrumen promosi terhadap niat pindah kerja.

Penelitian ini memberikan kontribusi terhadap teori keadilan organisasi dengan memberikan bukti empiris peran keadilan distributif dan instrumen promosi terhadap niat pindah kerja. Kontribusi praktis penelitian ini adalah penelitian ini memberikan informasi bagi manajemen perlunya perusahaan mengimplementasikan sistem insentif yang adil sebagai salah satu alat pengendalian mana- jemen yang dapat digunakan untuk menurunkan tingkat perpindahan kerja karyawan.

\section{TINJAUAN PUSTAKA DAN PERUMUSAN HIPOTESIS}

\section{Keadilan Distributif dan Instrumen Promosi}

Keadilan distributif dalam kinerja organisasi adalah "keyakinan akan keadilan hasil yang diterima oleh masing-masing karyawan dalam organisasi (Folger dan Cropanzano 1998). Rawls (2005) menyatakan bahwa berdasarkan teori keadilan (justice theory), karyawan mempunyai hak untuk mendapatkan keadilan yang sama. Karyawan menggunakan usaha, kemampuan dan pengalaman untuk mendapatkan imbalan/penghargaan yang berupa gaji dan promosi. Leventhal (1976), menyatakan bahwa berdasarkan teori ekuitas (equity theory) setiap individu dalam organisasi (karyawan) harus mendapat penghargaan dari organisasi sesuai dengan proporsi kontribusi yang telah mereka berikan pada organisasi. Penelitian terdahulu menunjukkan keadilan distributif berhubungan dengan instrumen promosi (Dubinsky dan Levy 1989). Penelitian Parker et al (2011) memberikan bukti empiris terdapat pengaruh positif signifikan antara keadilan distributif dan instrumen promosi. Dubinsky dan Levy (1989) menemukan bukti bahwa jika karyawan merasa penghargaan organisasi dijalankan secara adil (keadilan distributif tinggi), karyawan akan meyakini bahwa organisasi tersebut memiliki instrumen promosi yang tinggi. Berdasarkan landasan teori dan hasil penelitian empiris tersebut, hipotesis 1 penelitian ini dinyatakan sebagai berikut:

$\mathrm{H}_{1}$ : Keadilan distributif berpengaruh positif terhadap instrumen promosi

\section{Instrumen Promosi dan Niat Pindah Kerja}

Dalam mempertahankan dan meningkatkan produktifitas karyawan, perusahaan perlu memperhatikan kebutuhan karyawannya, baik kebutuhan materil maupun non materil. Wujud dari perhatian, usaha serta dorongan yang dapat diberikan perusahaan untuk mempertahankan karyawannya adalah dengan mem- 
berikan promosi jabatan yang objektif dan adil serta penempatan yang tepat. Shun (2011) menyatakan bahwa faktor utama penyebab karyawan memiliki keinginan berpindah kerja adalah ketidakadilan perusahaan dalam gaji dan promosi. Mathis dan Jackson (2002) mengidentifikasikan bahwa keluar-masuknya (turnover) karyawan berhubungan dengan ketidakadilan kerja (penerimaan gaji dan kesempatan promosi). Berdasarkan teori keadilan (justice theory) (Rawls 2005), setiap karyawan yang ada dalam perusahaan memiliki hak dan kesempatan yang sama besar untuk bisa mendapatkan promosi. Teori keadilan menyatakan bahwa hasrat alami manusia adalah untuk mencapai kepentingan pribadinya terlebih dahulu lalu mencapai kepentingan umum. Hasrat pencapaian kepentingan pribadi adalah suatu kebahagiaan yang merupakan ukuran pencapaian keadilan (Rawls 2005). Mendapatkan kesempatan promosi dari perusahaan merupakan suatu bentuk pencapaian yang baik untuk karyawan. Untuk itu, semakin tinggi kesempatan promosi yang diberikan perusahaan kepada karyawannya, maka akan menurunkan keinginan pindah kerja dan begitu sebaliknya (Parker et al. 2011). Penelitian Parker et al. (2011) memberikan bukti empiris bahwa instrumen promosi berpengaruh negatif terhadap keinginan pindah kerja. Hipotesis 2 penelitian ini dinyatakan sebagai berikut:

$\mathrm{H}_{2}$ : Instrumen promosi berpengaruh negatif terhadap niat pindah kerja

Penelitian ini selain bertujuan untuk menguji pengaruh instrumen promosi terhadap niat pindah kerja $\left(\mathrm{H}_{2}\right)$, juga ingin menguji peran kinerja sebagai variabel yang memoderasi hubungan instrumen promosi terhadap niat pindah kerja karyawan. Apakah kinerja karyawan akan memperkuat atau memperlemah keinginan pindah kerja ketika terdapat instrumen promosi. Jika karyawan yang memiliki prestasi kerja yang baik namun hanya menerima instrumen promosi yang rendah, maka karyawan tersebut cenderung akan meninggalkan organisasi karena mereka merasa prestasi kerja yang baik tidak dihargai oleh organisasi. Berdasarkan hal tersebut, mereka akan berusaha untuk mencari organisasi yang akan lebih menghargai kinerja mereka dengan sebuah promosi dibandingkan dengan karyawan yang memiliki kinerja yang rendah (Parker et al. 2011). Teori keadilan menyatakan bahwa siapapun bisa mendapatkan instrumen promosi tersebut. Dengan demikian, karyawan merasa termotivasi untuk terus meningkatkan kinerjanya dengan harapan karyawan akan memperoleh imbalan, salah satunya promosi jabatan yang telah disediakan oleh perusahaan (Vroom 1964). Jika karyawan memiliki kinerja yang tinggi dan perusahaan menyediakan instrumen promosi yang baik, maka keinginan pindah kerja akan turun. Berdasarkan hal tersebut, hipotesis 3 penelitian dinyatakan sebagai berikut:

$\mathrm{H}_{3}$ : Prestasi kerja karyawan memoderasi hubungan antara instrumen promosi terhadap niat pindah kerja. Hubungan terbalik antara instrumen promosi dan niat pindah kerja akan lebih kuat dengan prestasi kerja karyawan yang baik dibandingkan dengan prestasi kerja yang buruk.

\section{Keadilan Distributif dan Kinerja}

Keadilan distributif adalah penilaian karyawan mengenai keadilan atas hasil yang diterima karyawan dari organisasi (Greenberg 1990). Tujuan keadilan distribusi ini adalah kesejahteraan sehingga yang didistribusikan biasanya berhubungan dengan sumber daya ekonomi atau keuntungan. Keadilan distribusi dalam organisasi dapat menimbulkan kepuasan yang berdampak pada peningkatan prestasi kerja karyawan (Deutsch 1975). Semakin baik keadilan distributif dijalankan, maka akan berdampak positif terhadap kinerja karyawan. Penelitian terdahulu menunjukkan bahwa keadilan distributif memengaruhi kinerja (Cropanzano dan Greenberg 1997; Nasurdin dan Khuan 2007). Penelitian Rupp dan Cropanzano (2002) menunjukkan bahwa individu akan menampilkan tingkat kinerja dan tingkat komitmen yang lebih tinggi, peningkatan kepuasan, dan peningkatan tingkat kepercayaan ketika mereka merasa bahwa proses pengambilan keputusan adil, dan mereka diperlakukan dengan adil (Rupp dan 
Cropanzano 2002). Berdasarkan argumen tersebut, maka hipotesis 4 penelitian dinyatakan sebagai berikut:

$\mathrm{H}_{4}$ : Keadilan distributif berpengaruh positif terhadap prestasi kerja (job performance)

\section{Kinerja dan Niat Pindah Kerja}

Prestasi kerja yang baik akan berdampak secara negatif terhadap turnover intention. Hal itu karena karyawan cenderung akan lebih merasa nyaman bekerja dalam perusahaan yang memotivasi karyawannya untuk menghasilkan kinerja atau prestasi kerja (Lee dan Mitchell 1994). Jika sebuah organisasi tidak dapat memotivasi karyawannya untuk meningkatkan kemampuan, maka pengetahuan dalam organisasi tidak akan dapat dipraktikkan secara maksimal (Vroom 1964). Lee dan Mitchell (1994) menyatakan bahwa perpindahan kerja terjadi karena karyawan menghadapi masalah dalam lingkungan kerja yang menyebabkan mereka untuk berfikir berhenti dari pekerjaan mereka. Masalah tersebut didasari atas penilaian kinerja yang buruk yang merupakan sebuah sinyal bahwa mereka tidak mungkin bisa mendapatkan penghargaan dari perusahaan dan keadaan ini bisa menghasilkan dampak langsung pada keinginan untuk berpindah. Beberapa penelitian menemukan adanya hubungan negatif antara prestasi kerja terhadap niatt pindah kerja karyawan. Lum et al. (1998) dan Tett dan Meyer (1993) menemukan semakin tinggi tingkat prestasi kerja seseorang, maka semakin rendah keinginannya untuk meninggalkan pekerjaannya. Studi lainnya yang dikemukakan Kalbers dan Fogarty (1995) menunjukkan bahwa prestasi kerja dan niat pindah kerja mempunyai hubungan negatif. Berdasarkan hal tersebut, maka hipotesis 5 penelitian dinyatakan sebagai berikut:

$\mathrm{H}_{5}$ : Prestasi kerja (job performance) berpengaruh negatif terhadap niat pindah kerja

\section{Model Penelitian}

Dari penjelasan di atas model penelitian yang dibentuk tersaji pada gambar 1 di bawah.

\section{METODA PENELITIAN}

\section{Sampel}

Sampel penelitian ini adalah karyawan perusahaan perbankan di Indonesia. Perhitungan jumlah sampel yang digunakan adalah dari Roscoe (1975) yang menyebutkan bahwa ukuran sampel sebaiknya minimal 10 kali dari jumlah variabel dalam studi dan maksimal sebesar 500. Pada penelitian ini jumlah variabel yang diteliti sebanyak 4 variabel, maka ukuran sampel minimal sebanyak $10 \times 4=40$ responden. Teknik yang dilakukan dalam pengambilan sampel adalah melalui snowballing sampling, yaitu teknik pengumpulan sampel dari responden yang berasal dari referensi suatu jaringan, misalnya lewat group di internet (Hartono 2004).

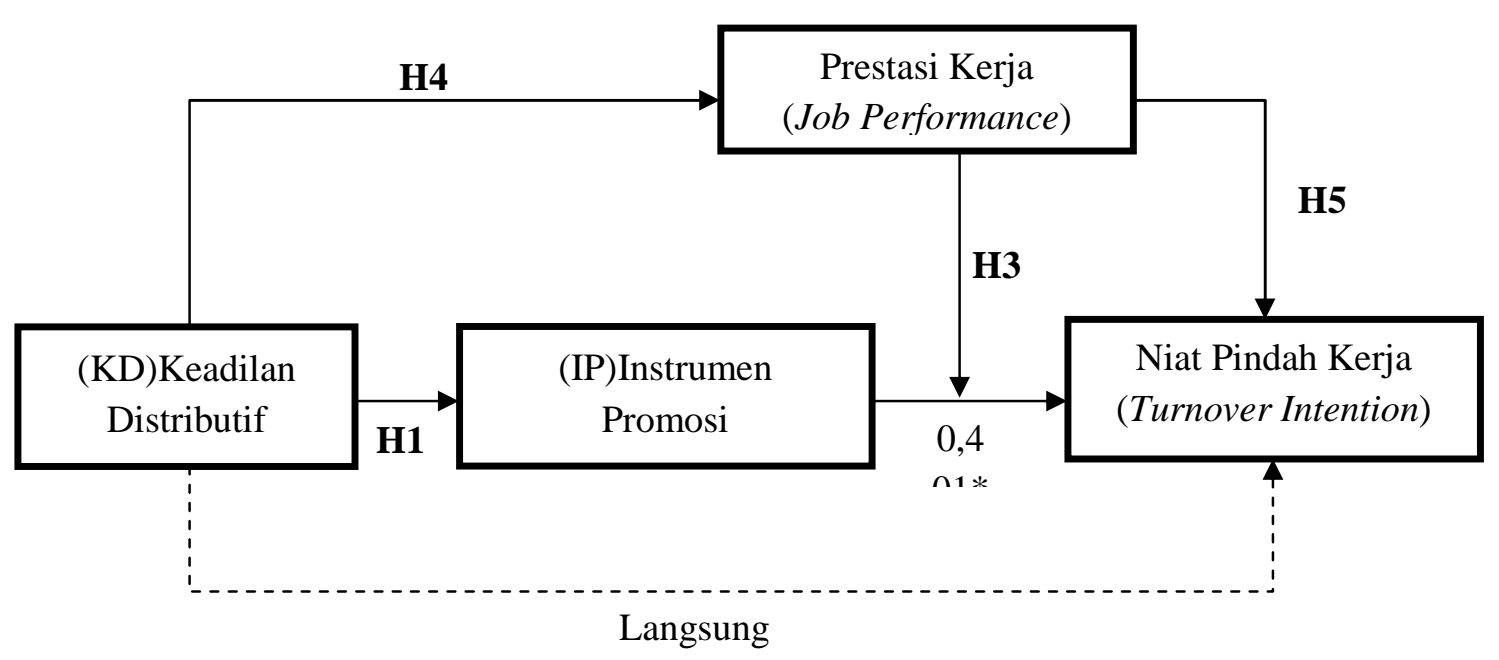

Gambar 1: Model Penelitian 


\section{Pengumpulan Data}

Data penelitian ini diperoleh melalui penyebaran kuesioner secara online. Kuesioner dikirimkan ke responden melalui email dan lewat situs jaringan (website). Kuesioner tersebut ditempatkan dalam sebuah akun dalam google, yaitu google form. Google form merupakan suatu aplikasi yang dibuat untuk keperluan survey menggunakan kuisioner secara online. Dari akun google form tersebut peneliti mendapatkan sebuah alamat website berupa link yang siap untuk disebarkan. Data diperoleh dengan membagikan link kuisioner online tersebut melalui jaringan komunikasi pribadi atau melalui email kepada responden yang relevan dengan penelitian. Data hasil survey dari responden akan secara otomatis masuk ke dalam Ms.excel setelah responden selesai mengisi kuisioner online tersebut.

\section{Definisi Operasional Variabel dan Peng- ukuran}

Terdapat empat variabel dalam dalam penelitian ini. Variabel dependen penelitian ini adalah niat pindah kerja (turnover intention), variabel independen penelitian adalah keadilan distibutif, variabel intervening adalah instrumen promosi, dan variabel moderasi sekaligus mediasi adalah kinerja (job performance).

Keadilan Distributif dalam penelitian ini didefiniskikan sebagai penilaian karyawan mengenai keadilan atas hasil (outcome) yang diterima karyawan dari organisasi (Greenberg 1990). Keadilan distributif diukur menggunakan kuesioner yang dikembangkan oleh Colquitt (2001). Kuesioner untuk mengukur keadilan distributif berisi empat pertanyaan, seperti "Gaji saya mencerminkan kontribusi saya dalam organisasi." Responden dapat memilih menggunakan skala likert $(1=$ sangat tidak setuju sampai 7 = sangat setuju).

Instrumen Promosi didefinisikan sebagai adanya kesempatan promosi berupa kenaikan jabatan di dalam suatu organisasi yang melibatkan peningkatan upah, gaji maupun status. Instrumen promosi diukur menggunakan kuesioner yang dikembangkan Colquitt (2001). Kuesioner untuk mengukur instrumen promosi berisi tiga pertanyaan, seperti "Dalam perusahaan saya, jika saya meningkatkan kinerja saya, maka akan menaikkan kesempatan untuk promosi (kenaikan jabatan) bagi saya." Responden dapat menilai dengan skala likert 1 (sangat tidak setuju) sampai skala 7 (sangat setuju).

Kinerja (Job Performance) didefinisikan sebagai hasil kerja yang dicapai oleh seorang karyawan dengan standar yang telah ditentukan. Variabel kinerja diukur dengan menggunakan kuesioner yang dikembangkan oleh Day dan Silverman (1989). Kuesioner untuk mengukur kinerja berisi enam pertanyaan dengan skala likert yang berkisar antara 1 (sangat tidak setuju) sampai dengan 5 (sangat setuju).

Niat pindah kerja (Turnover Intention) didefinisikan sebagai keinginan karyawan untuk berpindah kerja, belum sampai pada tahap realisasi yaitu melakukan perpindahan dari satu tempat kerja ke tempat kerja lainnya. Variabel niat pindah kerja diukur dengan menggunakan kuesioner yang dikembangkan oleh London dan Howat (1978). Kuesioner niat pindah kerja berisi tiga pertanyaan, seperti "Kalau tidak karena situasi yang tak terduga, saya berniat untuk tetap tinggal dengan perusahaan saya saat ini." Skala likert untuk merespon memiliki tujuh skala likert $(1=$ sangat tidak setuju; $7=$ sangat setuju).

\section{Alat Analisis Data}

Data penelitian ini dianalisis menggunakan analisis regresi linier untuk pengujian hipotesis 1, 2, 4, dan 5. Tujuan dari regresi ini adalah untuk mengetahui pengaruh antara variabel independen terhadap variabel dependen serta perbedaan tingkat pengaruhnya (Ghozali 2011). H3 diuji dengan metode MRA (moderated regression analysis). MRA merupakan bentuk regresi yang dirancang secara hirarki untuk menentukan hubungan antara dua variabel yang dipengaruhi oleh variabel moderasi.

\section{HASIL DAN PEMBAHASAN}

Berdasarkan link kuisioner yang disebar secara online, data yang masuk sebanyak 154 
responden, namun tidak seluruhnya dapat dipakai untuk perhitungan statistik karena sebanyak 15 responden dinyatakan tidak sesuai dengan karakteristik sampel yang digunakan. Data yang dapat diolah secara statistik sejumlah 139 responden karyawan industri perbankan. Jumlah responden menurut jenis kelamin cukup berimbang, yaitu laki-laki sebanyak 71 dan perempuan 68. Usia mayoritas responden relatif masih muda, sebanyak $79,8 \%$ berusia di bawah 30 tahun. Sebagian besar responden memiliki masa kerja kurang dari lima tahun (82\%). Sementara itu jika dilihat dari jabatan mereka dalam organisasi, reponden terbanyak dalam penelitian ini memiliki posisi sebagai staf $(64, \%)$. Karakteristik responden dapat dilihat pada tabel 1 .

Berdasarkan hasil analisis statistik deskriptif, diketahui bahwa penilaian responden terhadap keadilan distribusi memiliki nilai rata-rata sebesar 4,6583 dengan deviasi standar sebesar 1,55955, termasuk dalam penilaian yang tinggi, karena di atas nilai tengah (4). Hasil penilaian responden terhadap instrumen promosi memiliki nilai rata-rata sebesar 5,3812 (deviasi standar 1,38468; median 4). Penilaian responden terhadap prestasi kinerja memiliki nilai rata-rata sebesar 3,9532 (deviasi standar 0,68398; median 3). Hasil penilaian responden terhadap niat pindah kerja memiliki nilai rata-rata sebesar 3,9544 (deviasi standar 1,70526; median 4). Hasil statistik deskriptif dapat dilihat pada tabel 2.

\section{Uji Validitas dan Reliabilitas Instrumen}

Uji validitas digunakan untuk menunjukkan kesahihan suatu instrumen. Untuk menguji validitas instrumen penelitian digunakan rumus Product Moment Pearson, yaitu mengkorelasikan skor butir pernyataan dalam angket dengan skor komposit/faktor butir- butirnya. Suatu instrumen dapat dinyatakan valid jika koefisien korelasi > $\mathrm{r}$ tabel. Berpedoman pada sampel sebanyak 139 orang, pada level signifikan 5\% dengan pengujian satu arah (one tail), diperoleh nilai $\mathrm{r}$ tabel sebesar 0,139. Hasil pengujian validitas menunjukkan koefisien korelasi instrumen berkisar dari 0,784-0,971. Koefisien korelasi semua butir dengan skor total nilainya lebih besar dari nilai $r$ tabel (0.139) sehingga semua butir instrumen pertanyaan dapat dinyatakan valid dan dapat digunakan untuk penelitian selanjutnya.

Tabel 1: Karakteristik Responden

\begin{tabular}{|c|c|c|}
\hline Karakteristik & Jumlah & $\%$ \\
\hline \multicolumn{3}{|l|}{ Jenis Kelamin } \\
\hline - Laki-laki & 71 & $51 \%$ \\
\hline - Perempuan & 68 & $49 \%$ \\
\hline \multicolumn{3}{|l|}{ Usia } \\
\hline$-<25$ & 63 & $45,3 \%$ \\
\hline$-25-30$ & 48 & $34,5 \%$ \\
\hline$->30$ & 28 & $20,1 \%$ \\
\hline \multicolumn{3}{|l|}{ Lama Kerja: } \\
\hline$-<3$ th & 76 & $54,7 \%$ \\
\hline$-3-5$ th & 38 & $27,3 \%$ \\
\hline$->5$ th & 25 & $18,0 \%$ \\
\hline \multicolumn{3}{|l|}{ Jabatan: } \\
\hline - Direktur & 1 & $0,7 \%$ \\
\hline - Assistant Manager & 1 & $0,7 \%$ \\
\hline - Internal Auditor & 5 & $3,6 \%$ \\
\hline - Customer Service & 10 & $7,2 \%$ \\
\hline - HRD & 2 & $1,4 \%$ \\
\hline - Collection & 4 & $2,9 \%$ \\
\hline - Manager & 5 & $3,6 \%$ \\
\hline - Administration & 3 & $2,2 \%$ \\
\hline - Programmer & 3 & $2,2 \%$ \\
\hline - Marketing & 1 & $0,7 \%$ \\
\hline - Secretary & 2 & $1,4 \%$ \\
\hline - Staff & 90 & $64,7 \%$ \\
\hline - Supervisor & 10 & $7,2 \%$ \\
\hline - Teller & 2 & $1,4 \%$ \\
\hline
\end{tabular}

Tabel 2: Statistik Deskriptif

\begin{tabular}{lccccc}
\hline & $\mathrm{N}$ & Minimum & Maximum & Mean & Std. Dev. \\
\hline Keadilan Distributif & 139 & 1,00 & 7,00 & 4,6583 & 1,55955 \\
Instrumen Promosi & 139 & 1,67 & 7,00 & 5,3812 & 1,38468 \\
Prestasi Kerja & 139 & 1,17 & 5,00 & 3,9532 & 0,68398 \\
Niat Pindah Kerja & 139 & 1,00 & 7,00 & 3,9544 & 1,70526 \\
Valid N (listwise) & 139 & & & & \\
\hline
\end{tabular}


Uji reliabilitas atas instrumen penelitian menunjukkan Cronbach Alpha masing-masing variabel adalah keadilan distributif 0,947 , instrumen promosi 0,891 , kinerja 0,924 , dan niat pindah kerja 0,953 . Nilai tersebut menunjukkan bahwa instrumen yang digunakan dalam penelitian ini sudah memadai.

\section{Uji Hipotesis}

Hipotesis penelitian diuji dengan menggunakan regresi linear sederhana. Kemudian untuk menguji hipotesis 3 yaitu terkait pengujian pengaruh efek mediasi dari variabel instrumen promosi dan kinerja yang menghubungkan keadilan distributif terhadap niat pindah kerja digunakan analisis jalur. Tabel 3 dan 4 adalah hasil analisis regresi atas variabel penelitian.

Hipotesis pertama menyatakan bahwa keadilan distributif berpengaruh positif terhadap instrumen promosi. Berdasarkan hasil uji regresi linier sederhana, koefisien variabel keadilan distributif sebesar 0,516 $(\mathrm{t}=8,369 ; \mathrm{p}$ $<0,01)$. Hasil ini menunjukkan bahwa semakin tinggi keadilan distributif maka instrumen promosi akan semakin meningkat, begitu pula sebaliknya. Dengan demikian hipotesis pertama didukung.

Hipotesis kedua menyatakan bahwa instrumen promosi berpengaruh negatif terhadap niat pindah kerja. Berdasarkan hasil uji regresi diketahui bahwa variabel instrumen promosi mempunyai pengaruh negatif signifikan terhadap niat pindah kerja. Variabel instrumen promosi memiliki koefisien regresi sebesar $-0,401(\mathrm{t}=-4,031 ; \mathrm{p}<0,01)$. Hasil ini menunjukkan bahwa adanya kesempatan promosi yang semakin tinggi akan menurunkan niat pindah kerja karyawan. Dengan demikian hipotesis kedua penelitian didukung.

Hipotesis ketiga menyatakan bahwa prestasi kerja memoderasi hubungan antara instrumen promosi terhadap niat pindah kerja. Hubungan terbalik antara instrumen promosi dan niat pindah kerja akan lebih kuat apabila karyawan memiliki prestasi kerja yang baik dibandingkan dengan prestasi kerja yang buruk. Berdasarkan hasil analisis regresi moderasi sebagaimana ditunjukkan pada tabel 4 dapat diketahui bahwa interaksi antara instrumen promosi dengan kinerja mempunyai pengaruh negatif signifikan terhadap niat pindah kerja. Hal itu ditunjukkan dengan koefisien regresi sebesar $-0,082(t=-2,083 ; p$ $<0,05)$. Hasil tersebut dapat diartikan bahwa hubungan negatif antara instrumen promosi terhadap niat pindah kerja lebih kuat pada karyawan yang memiliki kinerja tinggi dibandingkan karyawan dengan kinerja rendah. Dengan demikian hipotesis ketiga penelitian ini didukung.

Tabel 3: Hasil Pengujian Regresi Sederhana

\begin{tabular}{lccc}
\hline \multicolumn{1}{c}{ Variabel } & Koefisien & t & p \\
\hline Keadilan Distributif terhadap Instrumen Promosi & 0,516 & 8,369 & 0,000 \\
Instrumen Promosi terhadap Niat Pindah Kerja & $-0,401$ & $-4,031$ & 0,000 \\
Keadilan Distributif terhadap Prestasi Kerja & 0,131 & 3,666 & 0,000 \\
Prestasi Kerja terhadap Niat Pindah Kerja & $-0,874$ & -4.380 & 0,000 \\
Keadilan Distributif terhadap Niat Pindah Kerja & $-0,398$ & $-4,580$ & 0,000 \\
\hline
\end{tabular}

Tabel 4: Hasil PengujianRegresi Moderasi

\begin{tabular}{lrrr}
\hline Variabel Dependen: Niat Pindah Kerja & Koefisien & t & p \\
\hline & & & \\
Konstanta & 7,765 & 6,897 & 0,000 \\
Instrumen Promosi & $-0,073$ & $-0,427$ & 0,670 \\
Prestasi Kinerja & $-0,421$ & $-1,560$ & 0,121 \\
Instrumen Promosi x Prestasi Kinerja & $-0,082$ & $-2,083$ & 0,039 \\
$\mathrm{R}^{2}=0,240 ; \mathrm{p}<0,001$ & & & \\
\hline
\end{tabular}


Hipotesis keempat menyatakan bahwa keadilan distributif berpengaruh positif terhadap prestasi kerja. Hasil uji regresi menunjukkan variabel keadilan distributif mempunyai pengaruh positif signifikan terhadap prestasi kerja. Hal ini ditunjukkan dengan nilai koefisien regresi sebesar 0,131 ( $\mathrm{t}=3,666 ; \mathrm{p}<$ $0,01)$. Hasil ini menunjukkan bahwa semakin tinggi keadilan distributif maka prestasi kerja karyawan akan semakin meningkat, begitu pula sebaliknya. Dengan demikian hipotesis keempat didukung.

Hipotesis kelima menyatakan bahwa prestasi kerja berpengaruh negatif terhadap niat pindah kerja. Hasil uji regresi menunjukkan variabel prestasi kerja mempunyai pengaruh negatif signifikan terhadap niat pindah kerja. Hal itu ditunjukkan dengan nilai koefisien regresi sebesar $-0,874(\mathrm{t}=-4,380 ; \mathrm{p}<$ 0,01). Hasil tersebut dapat diartikan bahwa semakin tinggi prestasi kerja karyawan maka keinginan pindah kerja semakin menurun, begitu pula sebaliknya. Dengan demikian hipotesis kelima dapat didukung.

\section{Analisis Jalur}

Hasil perhitungan pengaruh langsung (direct effect) dan tidak langsung (indirect effect) keadilan distributif terhadap niat pindah kerja melalui instrumen promosi dapat ditunjukkan sebagaimana tampak pada gambar 2 .

Berdasarkan hasil analisis jalur 1 ditemukan bahwa pengaruh langsung keadilan distributif terhadap niat pindah kerja sebesar 0,364 sedangkan pengaruh tidak langsung keadilan distributif melalui instrumen promosi sebesar -0,190. Dengan demikian pengaruh langsung lebih tinggi dibandingkan dengan pengaruh tidak langsung, sehingga dapat dinyatakan bahwa instrumen promosi tidak memediasi hubungan antara keadilan distributif terhadap niat pindah kerja.

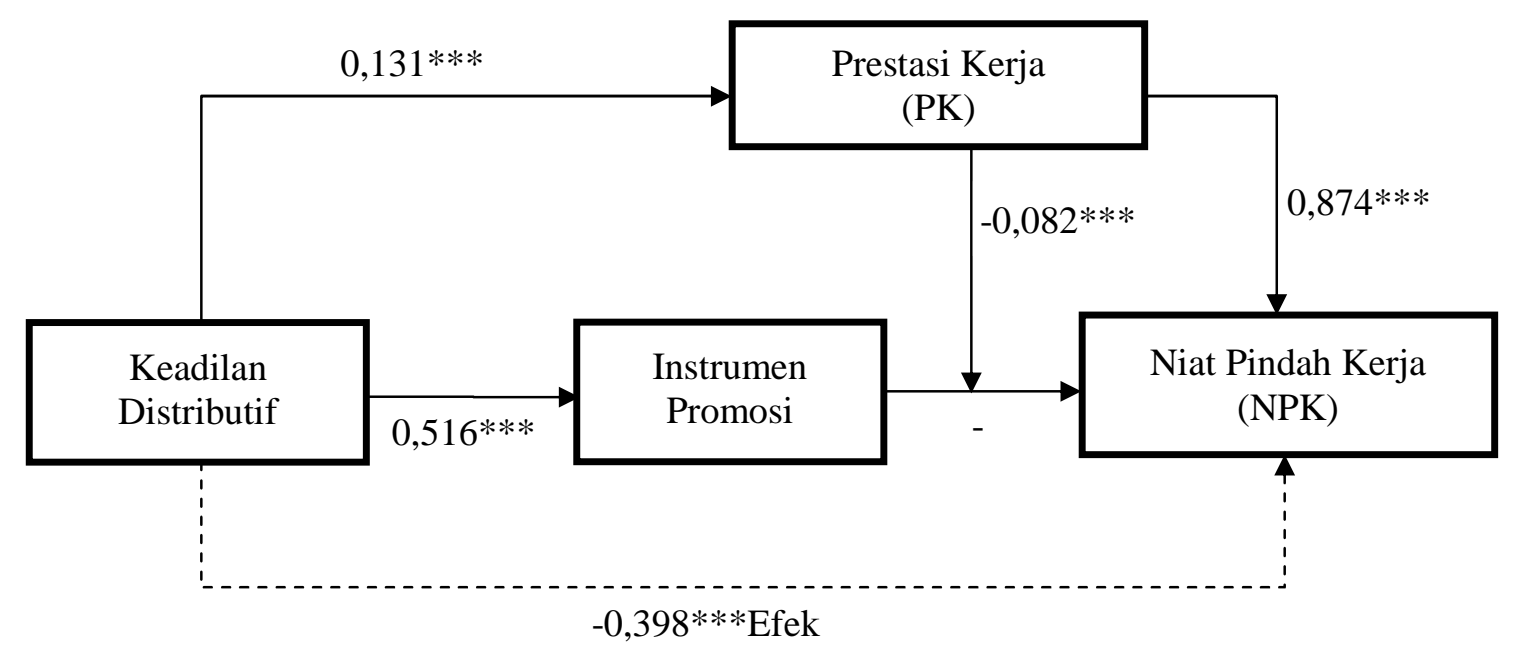

$* *=\mathrm{p}<0,05 ; * * *=\mathrm{p}<0,001$

Gambar 2: Analisis Jalur

Efek Langsung

Keadilan Distributif $\rightarrow$ Instrumen Promosi

Instrumen Promosi $\rightarrow$ Niat Pindah Kerja

Keadilan Distributif $\rightarrow$ Niat Pindah Kerja

Efek Tidak Langsung

Jalur 1: KD $\rightarrow$ IP $\rightarrow$ NPK

Jalur $2: \mathrm{KD} \rightarrow \mathrm{PK} \rightarrow \mathrm{NPK}$

Efek Tidak Langsung

Efek Langsung

Efek Total

$$
\begin{array}{lr}
= & 0,582 \\
= & -0,326 \\
= & -0,364
\end{array}
$$

\begin{tabular}{lll}
$0,582 \times-0,326$ & $=$ & $-0,190$ \\
$0,299 \times-0,350$ & $-0,105$ \\
\cline { 2 - 3 } & $\begin{array}{r}-0,295 \\
\end{array}$ \\
\cline { 2 - 2 } & $-0,364$ \\
\hline
\end{tabular}


Berdasarkan hasil analisis jalur 2 diketahui bahwa pengaruh tidak langsung keadilan distributif terhadap niat pindah kerja melalui prestasi kerja adalah sebesar $-0,105$, sedangkan pengaruh langsungnya adalah 0,364 . Dengan demikian pengaruh langsung lebih tinggi dibandingkan dengan pengaruh tidak langsung, sehingga dapat dinyatakan bahwa prestasi kerja tidak memediasi hubungan antara keadilan distributif terhadap niat pindah kerja. Berdasarkan hasil perhitungan analisis jalur di atas, maka dapat disimpulkan bahwa variabel instrumen promosi dan prestasi kerja bukan sebagai variabel pemediasi, karena pengaruh langsung antara keadilan distributif terhadap niat pindah kerja lebih besar dibandingkan dengan pengaruh tidak langsungnya.

Penelitian ini menemukan bahwa keadilan distributif berpengaruh signifikan terhadap niat pindah kerja, baik secara langsung maupun tidak langsung melalui instrumen promosi dan prestasi kerja sebagai variabel mediasi. Berdasarkan analisis pengaruh tidak langsung, variabel prestasi kerja dan instrumen promosi memediasi hubungan antara keadilan distributif terhadap niat pindah kerja. Untuk variabel prestasi kerja, selain berperan memediasi hubungan keadilan distributif terhadap niat pindah kerja, variabel prestasi kerja juga memoderasi hubungan antara instrumen promosi dengan niat pindah kerja. Hal ini dapat diinterpretasikan bahwa pengaruh keadilan distributif dan instrumen promosi terhadap niat pindah kerja tergantung pada prestasi kerja karyawan. Karyawan yang prestasi kerjanya tinggi namun perusahaan tidak memberikan keadilan distributif serta tidak memiliki instrumen promosi yang baik maka kondisi tersebut akan meningkatkan kecenderungan karyawan meninggalkan perusahaan. Sementara itu bagi karyawan yang prestasi kerjanya rendah, mereka cenderung untuk tidak keluar dari perusahaan karena dengan kinerjanya yang rendah mereka sulit untuk mendapatkan promosi dan tidak dapat bersaing di pasar tenaga kerja. Karyawan yang meyakini bahwa perusahaan memberikan keadilan distributif juga mempersepsikan per- usahaan tersebut juga akan memberikan instrumen promosi yang adil. Hal ini ditunjukkan dengan adanya pengaruh positif signifikan antara keadilan distributif terhadap instrumen promosi. Adanya pengaruh negatif signifikan antara instrumen promosi dengan niat pindah kerja memberikan arti bahwa semakin tinggi peluang karyawan mendapatkan kesempatan promosi (kenaikan pangkat/jabatan), maka akan mengurangi keinginan keluar dari perusahaan.

Hasil penelitian ini secara umum menunjukkan bahwa karyawan yang berprestasi tinggi akan melihat apakah perusahaan telah memberikan keadilan distributif dan menyediakan instrumen promosi sebagai pertimbangan mereka tetap bertahan atau akan keluar dari perusahaan. Oleh karena itu, bagi perusahaan sangat penting membangun sistem pengendalian manajemen yang menjamin adanya keadilan distributif dan instrumen promosi yang baik untuk mempertahankan karyawan yang berprestasi agar tidak keluar dari perusahaan. Perusahaan perlu fokus pada usaha mempertahankan karyawan berprestasi tinggi sebab biaya mempertahankan karyawan berprestasi lebih rendah dibandingkan biaya merekrut, melatih, dan mendidik karyawan baru. Secara keseluruhan, temuan penelitian ini mendukung penelitian yang dilakukan Parker et al (2011), Zimmerman dan Darnold (2007), serta Kalbers dan Fogarty (1995).

\section{SIMPULAN}

Penelitian ini memberikan kesimpulan bahwa keadilan distributif berpengaruh positif signifikan terhadap instrumen promosi, selanjutnya instrumen promosi berpengaruh negatif signifikan terhadap niat pindah kerja. Pengaruh instrumen promosi terhadap niat pindah kerja ditergantung pada prestasi kerja karyawan. Prestasi kerja karyawan akan memperkuat pengaruh antara instrumen promosi terhadap niat pindah kerja. Hubungan negatif antara instrumen promosi terhadap niat pindah kerja akan semakin kuat jika prestasi karyawan tinggi dibandingkan jika karyawan memiliki prestasi kerja rendah. Penelitian ini juga memberikan hasil bahwa keadilan distributif 
berpengaruh positif signifikan terhadap prestasi kerja, selanjutnya prestasi kerja berpengaruh negatif signifikan terhadap niat pindah kerja. Namun berdasarkan hasil analisis jalur, pengaruh keadilan distributif terhadap niat pindah kerja cenderung bersifat langsung tidak dimediasi oleh variabel instrumen promosi dan prestasi kerja.

Penelitian ini memiliki keterbatasan yaitu penelitian ini melibatkan sampel penelitian dalam jumlah terbatas yang diambil dari perusahaan perbankan. Penggunaan sampel pada industri yang berbeda mungkin akan memberikan hasil yang berbeda. Disarankan untuk peneliti selanjutnya agar memperluas sampel penelitian. Selain itu perlu diuji pengaruh variabel lain selain keadilan distributif, misalnya keadilan prosedural, keadilan interaksional, dan keadilan informasional.

\section{DAFTAR REFERENSI}

Alexander, S. dan Rudeman, M. 1987. The role of procedural and distributive justice in organizational behavior. Social Justice Research 1 (2): 177-198.

Almer, E., dan S. Kaplan. 2002. The effects of flexible work arrangements on stressors, burnout, and behavioral job outcomes in public accounting. Behavioral Research in Accounting 14 (1): 1-34.

Colquitt, J. 2001. On the dimensionality of organizational justice: A construct validatio of a measure. Journal of Applied Psychology 86 (3): 386-400.

Cropanzano, R., dan J. Greenberg. 1997. Progress in organizational justice: Tunneling through the maze. International Review of Industrial and Organizational Psychology 12: 617-372.

Dalton, D., J. Hill, dan R. Ramsay. 1997. Women as managers and partners: Context specific predictors of turnover in international public accounting firms. Auditing: A Journal of Practice \& Theory 16 (1): 29-50.

Day, D., dan S. Silverman. 1989. Personality and job performance: Evidence of incremental validity. Personnel Psychology 42 (1): 25-36.

Deutsch, M. 1975. Equity, equality and need: What determine which value will be used as the basis for distributive justice?. Journal of Social Issue 31 (3): 137-149.

Dubinsky, A., dan M. Levy. 1989. Influences of organizational fairness on work outcomes of retail salespeople. Journal of Retailing 65 (2): 221-252.

Fogarty, T., J. Singh, G. Rhoads, dan R. Moore. 2000. Antecedents and consequences of burnout in accounting: Beyond the role stress model. Behavioral Research in Accounting 12: 31-67.

Folger, R., dan R. Cropanzano. 1998. Organizational justice and human resource management. Thousand Oaks, CA: Sage.

Ghozali, I. 2011. Aplikasi analisis multivariate dengan program IBM SPSS. Edisi kelima Semarang: Badan Penerbit Universitas Diponegoro.

Greenberg, J. 1990. Organizational Justice: Yesterday, today, and tomorrow. Journal of Management 16 (2): 399432.

Harrell, A., dan R. Eickhoff. 1988. Auditors' influence-orientation and their affective responses to "big eight" work environment. Auditing: A Journal of Practice \& Theory 7: 105-118.

Hartono, J. 2004. Metodologi Penelitian Bisnis. Edisi keenam. Yogyakarta: BPFE Yogyakarta.

Holtz, B. C., dan C. M. Harold. 2009. Fair today, fair tomorrow? A Longitudinal investigation of overall justice perceptions. Journal of Applied Psychology 94 (5): 1185-1199.

Kalbers, L., dan T. J. Fogarty. 1995. Professionalism and its consequences: A Study of internal auditors. Auditing: A Journal of Practice \& Theory 14 (1): 65-86. 
Lee, T.W., dan T. R. Mitchell. 1994. An alternative approach: The unfolding model of voluntary employee turnover. Academy of Management Review 19 (1): 51-89.

Leventhal, G. 1976. The Distribution of Rewards and Resources in Groups and Organizations. In Advances in Experimental Social Psychology 9: 91-131.

London, M., dan G. Howat. 1978. The Relationship between commitment and conflict resolution behavior. Journal of Vocational Behavior 13 (1): 1-14.

Lum, L., J. Kervin, K. Clark, F. Reid, dan W. Sirola. 1998. Explaining nursing turnover intent: Job satisfaction, pay satisfaction, or organizational commitment. Journal of Organizational Behavior 19 (3): 305- 320.

Mathis, R. L., dan J. H. Jackson. 2002. (Human Resource Management) Manajemen Sumber Daya Manusia. Jakarta: Salemba Empat.

Nasurdin, A. M., dan S. L. Khuan. 2007. Organizational justice as an antecedent of job performance. Gadjah Mada International Journal of Business 9 (3): 335-353.

Parker, R., and J. Kohlmeyer. 2005. Organizational justice and turnover in public accounting firms: A research note. Accounting, Organizations and Society 30 (4): 357-369.

Parker, R. J., H. Nouri, dan A. F. Hayes. 2011. Distributive justice, promotion instru mentality, and turnover intention in public accounting firm. Behavioral Research in Accounting 23 (2): 169-186.

Pasewark, W., dan R. Viator. 2006. Sources of work-family conflict in the accounting profession. Behavioral Research in Accounting 18 (1): 147-165.

Rawls, J. 2005. A Theory of justice. Cambridge: Belknap Press.
Ridlo, I. A. 2012. Turnover karyawan: Kajian literatur. Surabaya: PHMovement Publication.

Rupp, D. E., dan Cropanzano, R. 2002. Multi justice and social exchange relationship. Organizational Behavior and Human Decision Processes 89: 925-946.

Roscoe, J. T. 1975. Fundamental research statistic for the behavior sciencess. New York: Holt, Rinehart and Winston.

Scandura, T., dan R. Viator. 1994. Mentoring in public accounting firms: An analysis of mentor-protege relationships, mentorship functions, and protege turnover intentions. Accounting, Organizations and Society 19 (8): 717-734.

Shun, K. 2011. The turnover intentions for construction engineers. Journal of Marine Science and Technology 19 (5): 550-556.

Sidharta, N., dan M. Margaretha. 2011. Dampak komitmen organisasi dan kepuasan kerja terhadap turnover intention; Studi empiris pada karyawan bagian operator di salah satu perusahaan garment di Cimahi. Jurnal Manajemen 2 (10): 129-142.

Tett, R. P., dan J. P. Meyer. 1993. Job satisfaction, organizational commitment, turnover intention, and turnover: Path analyses based on meta-analytic findings. Personnel Psychology 46 (2): 259-293.

Toly, A. R. 2001. Analisis faktor-faktor yang mempengaruhi turnover intention pada staf akuntan publik. Jurnal Akuntansi \& Keuangan 3 (2): 102-125.

Vroom, V. 1964. Work and motivation. New York: John Wiley \& Sons.

Zimmerman, R. D., dan C. T. Darnold. 2007. The impact of job performance on employee turnover intentions and the voluntary turnover process. International Journal of Business and Society 38 (2): 142-158. 